\title{
ANALISIS PENERAPAN AKUNTANSI PERSEDIAAN BERDASARKAN PSAK NO.14 PADA PT. GATRACO INDAH MANADO
}

\author{
Rachel Anly Marilyn Lingkanwene Wullur ${ }^{1}$ \\ Herman Karamoy ${ }^{2}$ \\ Winston Pontoh ${ }^{3}$ \\ ${ }^{1,2,3}$ Fakultas Ekonomi dan Bisnis, Jurusan Akuntansi \\ Universitas Sam Ratulangi \\ Email : ${ }^{1}$ rachelanly@gmail.com
}

\begin{abstract}
Inventories are assets owned by the company that are available for sale or goods that will be used in the production of the company's product. With inventory, the company can sustain their sustainability. Companies often experienced problems in recording and assessment the inventories itself. Aim to make this observation on PT Gatraco Indah is to determine the suitability on the application of the inventory recording method and inventory valuation method of manufacture inventory in the PT Gatraco Indah with Statement of Financial Accounting Standards (SFAS) 14 about Inventory. PT Gatraco Indah is a company engaged in food and beverages for airline companies in Indonesia, especially in North Sulawesi. The Methods that was used in this research is descriptive research method with qualitative analysis techniques outline, describe and compare the data. The Result of this research shows that the company has applied the PSAK No.14 on their inventories.
\end{abstract}

Keywords: inventory recording method, inventory valuation methods

\section{Latar Belakang}

\section{PENDAHULUAN}

Perusahaan yang bergerak dalam industri perdagangan berusaha memanfaatkan semua sumber daya yang dimilikinya seefektif dan seefisien mungkin, sumber daya tersebut di antaranya adalah persediaan yang informasinya sangat diperlukan oleh pihak manajemen dalam pengambilan keputusan agar tidak terjadi kelebihan ataupun kekurangan persediaan. Masalah persediaan merupakan permasalahan yang selalu dihadapi para pengambil keputusan dalam proses produksi, pencatatan persediaan dilakukan untuk menjamin adanya kepastian bahwa pada saat dibutuhkan barang-barang tersebut tersedia.

Pernyataan Standar Akuntansi Keuangan (PSAK) No.14 (Ikatan Akuntan Indonesia, 2015:14.2) persediaan adalah aset yang tersedia untuk dijual dalam kegiatan usaha biasa, dalam proses produksi penjualan tersebut atau dalam bentuk bahan atau dalam bentuk perlengkapan untuk digunakan dalam proses produksi atau pembelian jasa. Persediaan termasuk dalam aktiva lancer dikarenakan jumlah kas akan bertambah seiring dengan penjualan barang secara tunai.

Tetapi terkadang dalam pencatatan ataupun perlakuan akuntansi suatu perusahaan belum di lakukan dengan baik atau belum sesuai dengan standar akuntansi yang berlaku di Indonesia.Hal ini di karenakan beberapa faktor di antaranya kekurangan informasi terhadap metode pencatatan dan penilaian persediaan, kurangnya pengetahuan dari pihak perusahaan untuk menerapkan metode yang layak, ataupun perusahaan sudah merasa cocok dengan metode yang telah diterapkan dan digunakan selama ini sehingga perusahaan enggan untuk mengganti metode lama dengan metode baru yang sesuai dengan standar yang berlaku sebenarnya.

Dalam PSAK No.14 dijelaskan mengenai perlakuan akuntansi untuk persediaan, ruang lingkup yang dapat di golongkan sebagai persediaan, pengukuran persediaan, biaya-biaya yang mempengaruhi persediaan, dan juga mengenai pengungkapan persediaan.PT. Gatraco Indah Manado merupakan sebuah perusahaan yang bergerak di bidang food and baverages khusus untuk maskapai Garuda Indonesia dibagian Manado.

\section{Tujuan Penelitian}

Tujuan penelitian ini adalah untuk mengetahui adanya kesesuaian penerapan standar akuntansi persediaan yang diatur dalam PSAK No.14 dengan PT. Gatraco Indah Manado. 


\section{Pengertian Akuntansi}

\section{TINJAUAN PUSTAKA}

Belkaoui (2006:50) mendefinisikan akuntansi sebagai suatu aktivitas jasa yang berfungsi untuk memberikan informasi kuantitatif dari entitas ekonomi, terutama yang bersifat keuangan dan dimaksudkan untuk bermanfaat dalam pengambilan keputusan ekonomi, dan dalam menentukan pilihan di antara serangkaian tindakan-tindakan alternatif yang ada. Reeve (2009:9) menyatakan akuntansi secara umumnya dapat diartikan sebagai sistem informasi yang menyediakan laporan untuk para pemangku kepentingan mengenai aktivitas ekonomi dan kondisi perusahaan.

\section{Konsep Laporan Keuangan}

Ardiyos (2010:414) Laporan keuangan merupakan proses berkala yaitu menampilkan datadata keuangan tentang posisi suatu perusahaan, kinerja operasi, dan aliran dana-dana selama periode akuntansi untuk pihak-pihak di luar organisasi bisnis. Urutan tersebut adalah sebagai berikut:

a. Laporan Laba Rugi (Income Statement) merupakan laporan yang disusun secara sistematis tentang pendapatan dan pengeluaran suatu perusahaan atau organisasi untuk menunjukkan adanya laba atau kerugian untuk suatu periode tertentu.

b. Laporan Ekuitas Pemilik (Statement of Owner's Equity) merupakan suatu pernyataan atau laporan keuangan yang menunjukkan perubahan modal pemilik selama periode tertentu.

c. Neraca (Balance Sheet) merupakan suatu pernyataan tertulis yang mencerminkan mengenai aktiva, kewajiban dan juga modal suatu perusahaan pada suatu tanggal tertentu. Disebut neraca di karenakan kenyataannya terjadi keseimbangan antara aktiva di satu pihak dengan kewajiban dan modal pihak lain.

d. Laporan Arus Kas (Statement of Cash Flows) merupakan sebuah laporan yang menggambarkan penerimaan kas dan pembayaran kas selama periode waktu tertentu. Laporan ini memaparkan secara terperinci dari masing-masing aktivitas, yaitu mulai dari aktivitas operasi, aktivitas investasi, sampai pada aktivitas pendanaan/pembiayaan untuk satu periode waktu tertentu. Laporan arus kas juga menunjukan besarnya kenaikan ataupun penurunan bersih kas dari seluruh aktivitas dalam periode berjalan serta jumlah kas yang dimiliki suatu perusahaan sampai dengan akhir periode.

\section{Definisi Persediaan}

Menurut Hongren $d k k$ diterjemahkan oleh Muhamad (2009:216) persediaan merupakan seluruh barang dagangan yang dimiliki oleh perusahaan dan diharap dapat dijual dalam jalur normal operasi perusahaan.Ikatan Akuntan Indonesia (2015:14.2)persediaan meliputi barang yang dibeli dan dimiliki untuk dijual kembali.Seperti contoh, barang dagang yang dibeli oleh pengecer untuk dijual kembali, atau pengadaan tanah dan properti lainnya untuk dijual kembali. Persediaan juga mancakupi barang yang diproduksi, atau barang dalam penyelesaian yang sedang diproduksi oleh entitas serta termasuk bahan serta perlengkapan yang akan digunakan dalam proses produksi.

\section{Jenis-jenis Persediaan}

Terdapat beberapa golongan untuk pembagian jenis persediaan. Keown (2010:312) menjelaskan beberapa tipe umum persediaan beerdasarkan proses produksi sebagai berikut:

A. Persediaan Bahan Mentah (Raw Materials)

Terdiri dari bahan dasar yang dibeli dari perusahaan lain untuk digunakan dalam operasi produksi perusahaan.

B. Persediaan Barang Setengah Jadi (Work-in-Process)

Mencakup barang setengah jadi yang membutuhkan kerja tambahan atau proses lanjutan sebelum menjadi barang jadi.

C. Persediaan Barang Jadi (Finished Goods)

Mencakup barang yang telah selesai proses produksinya tetapi belum dijual oleh perusahaan, dan masih berada di dalam gudang

\section{Metode Pencatatan Persediaan}

Dalam akuntansi dikenal ada dua macam metode dalam pencatatan persediaan yang dikenal dengan metode perpetual dan metode periodik.

a. Metode perpetual 
Reeve (2009:282) setiap pembelian dan penjualan barang dicatat dalam akun persediaan dan juga pada akun harga pokok penjualan.Dengan demikian jumlah barang yang tersedia untuk dijual dan jumlah yang terjual dilaporkan dalam catatan persediaan secara terus-menerus.

b. Metode periodik

Reeve (2012:282) Pencatatan dalam metode fisik atau yang disebut juga dengan metode periodik, akun harga pokok penjualan dihitung dengan mengurangkan sisa barang pada akhir periode dari barang tersedia untuk dijual selama periode tersebut.Sisa barang pada akhir periode dihitung dengan melakukan perhitungan fisik terhadap sisa persediaan yang ada.Pada metode periodik catatan persediaan tidak menunjukan jumlah tersedia untuk dijual atau jumlah terjual salama periode tertentu.

\section{Harga Pokok Penjualan}

Harga pokok penjualan (HPP) terkait langsung dengan penerimaan penjualan.Penjualan dalam suatu periode akuntansi merupakan jumlah unit yang terjual dikalikan dengan harga jual, sedangkan harga pokok penjualan merupakan jumlah unit yang sama dikalikan dengan biaya per unit.

Supriyono (2008 : 16) mengartikan harga pokok adalah jumlah yang dapat diukur dalam satuan uang, dalam bentuk kas yang dibayarkan atau nilai jasa yang diserahkan/dikorbankan, atau hutang yang timbul atau tambahan modal dalam rangka pemilikan barang dan jasa yang diperlukan perusahaan, baik pada masa lalu maupun pada masa mendatang.

\section{Metode Penilaian Persediaan}

Metode penilaian persediaan ini mengalokasikan total biaya persediaan yang tersisa dan yang dijual. Metode ini terdiri dari empat metode paling umum yaitu:

a. Identifikasi Khusus

Pontoh (2013:312) metode ini memiliki keunggulan dalam menentukan secara tepat biaya persediaan per unit yang terjual, dan menentukan secara tepat nilai persediaan akhir yang tersisa dalam gudang.Hal ini disebabkan karena unit persediaan yang akan dijual dapat diidentifikasi terpisah secara tepat.Akan tetapi, metode ini menjadi tidak praktis ketika diterapkan dalam organisasi bisnis yang bergerak di bidang usaha perdagangan besar dan eceran.

b. Metode Biaya Rata-rata

Pontoh (2013:317) metode ini mengasumsikan bahwa harga beli sebuah persediaan yang dibeli terakhir akan menjadi beban pokok penjualam terlebih dahulu, pada saat terjadinya transaksi penjualan. Nilai persediaan yang akan dilaporkan adalah berdasarkan harga beli persediaan pada awal persediaan.

c. Metode Masuk Pertama, Keluar Pertama (FIFO)

Libby (2008:342) metode ini berasumsi bahwa barang yang pertama kali dibeli merupakan barang yang pertama kali dijual, dan barang yang terakhir kali dibeli merupakan barang yang tersisa sebagai persediaan.Menurut metode ini, harga pokok penjualan dan persediaan akhir dihitung seolah-olah barang tersebut keluar masuk.Saat metode FIFO digunakan selama periode inflasi atau kenaikan harga-harga secara umum, biaya unit yang lebih awal akan lebih rendah dibandingkan dengan biaya unit paling terakhir.Oleh karena itu metode ini akan menghasilkan laba kotor lebih tinggi.Akan tetapi, persediaan perlu diganti dengan harga yang lebih tinggi dari pada yang ditunjukan oleh harga pokok penjualan.

d. Metode Masuk Terakhir, Keluar Pertama (LIFO)

Reeve (2009:356) metode ini berasumsi bahwa barang yang dibeli paling terakhir merupakan barang yang pertama kali dijual, unit paling tua tetap berada dalam persediaan akhir. Ketika metode LIFO ini digunakan selama peiode inflasi atau kenaikan harga-harga, hasilnya adalah berkebalikan dengan metode-metode yang lain.Metode LIFO akan menghasilkan jumlah yang lebih tinggi untuk harga pokok penjualan (HPP), jumlah yang lebih rendah untuk laba kotor dan jumlah yang lebih rendah untuk persediaan akhir.Alasan pengaruh ini adalah biaya perolehan unit yang paling akhir akan kurang lebih sama dengan biaya penggantinya. Dalam periode inflasi, biaya unit yang lebih baru akan lebih tinggi dibandingkan dengan biaya unit yang lebih awal. 


\section{Pernyataan Standar Akuntansi Keuangan No.14 (PSAK No.14) tentang Persediaan}

Pernyataan Standar Akuntansi Keuangan atau PSAK adalah standar yang harus diikuti dalam pencatatan dan pelaporan akuntansi di Indonesia.PSAK ini merupakan aturan-aturan yang harus ditaati oleh para akuntan agar pelaporan akuntansi di Indonesia lebih efektif.

a. Persediaan

Dalam PSAK No.14, Ikatan Akuntansi Indoensia mengkhususkan pernyataannya mengenai persediaan. Ini terdiri dari bagian pendahuluan, penjelasan dan pengungkapan mengenai persediaan barang dagangan.

b. Pendahuluan

Dalam pendahuluan PSAK No.14 memuat tentang tujuan pernyataan, ruang lingkup pernyataan dan definisi persediaan.Pendahuluan ini terdiri dari paragraf 1 sampai dengan paragraf 4 .

c. Tujuan

Tujuan pernyataan ini adalah untuk merumuskan perlakuan akuntansi untuk persediaan menurut system biaya historis.Permasalahan pokok dalam akuntansi persediaan adalah jumlah biaya yang harus diakui sebagai aktiva dan konversi selanjutnya sampai pendapatan yang bersangkutan diakui.

d. Ruang Lingkup

Dalam paragraph 1 PSAK No.14 mengatakan bahwa: pernyataan ini harus diaplikasikan dalam penyusunan laporan keuangan dalam konteks system biaya historis tentang akuntansi persediaan selain:

1) Pekerjaan dalam proses yang timbu dalam kontrak konstruksi

2) Instrumen keuangan; dan

3) Persediaan yang dimiliki oleh produsen peternakan, produk pertanian dan kehutanan, dan hasil tambang sepanjang persediaan tersebut dinilai berdasarkan nilai realisasi bersih sesuai dengan kelaziman praktek yang berlaku dalam industry tertentu.

\section{Penelitian Terdahulu}

1. Djanegara (2004) dalam penelitiannya tentang : Evaluasi Metode Penilaian Persediaan Kaitannya Dengan Harga Pokok Penjualan, bertujuan untuk mengetahui dasar penilaian persediaan pada perusahaan serta penerapan metode penilaian persediaan berdasarkan PSAK No.14 yang berlaku di Indonesia PT.CLI. Jenis Penelitian ini adalah deskripstif kualitatif. Peneliti belum memberikan contoh pencatatan persediaan yang sesuai dengan PSAK No.14.

2. Sambuaga (2013) dalam penelitiannya tentang : Evaluasi Akuntansi Persediaan pada PT. Sukses Era Niaga Manado, bertujuan untuk mengetahui penerapan akuntansi persediaan pada PT. Sukses Era Niaga Manado apakah sudah sesuai dengan PSAK No.14 mengenai persediaan. Jenis penelitian ini adalah deskriptif kualitatif. Peneliti telah memberikan contoh pengungkapan persediaan yang sesuai dengan PSAK No.14.

3. Anwar (2014) dalam penelitiannya tentang : Analisis Penerapan Metode Pencatatan Dan Penilaian Terhadap Persediaan Barang Menurut PSAK No.14 Pada PT. Tirta Investama Dc Manado, bertujuan untuk mengetahui adanya kesesuaian penerapan metode pencatatan dan penilaian persediaan barang di PT. Tirta Investama dengan PSAK NO.14 tentang Persediaan. Peneliti telah memberikan contoh pengungkapan persediaan yang cukup sesuai dengan PSAK No.14.

\section{Jenis Penelitian}

\section{METODELOGI PENELITIAN}

Dalam Penilitian ini, Jenis penelitian yang digunakan adalah jenis penelitian kualitatif; dimana dalam penelitian yang dilakukan bersifat deskriptif yaitu untuk mengetahui atau menggambarkan kenyataan dari kejadian yang diteliti sehingga memudahkan penulis untuk mendapatkan data yang objektif dalam rangka mengetahui dan memahami metode pencatatan serta penilaian persediaan barang yang diterapkan oleh PT. Gatraco Indah.

\section{Tempat dan Waktu Penelitian}

Penelitian ini dilaksanakan di PT Gatraco Indah Manado, yang terletak di Jalan A.A Maramis No 245 Paniki Dua, Mapanget - Suawesi Utara.Penelitian dimulai pada bulan Agustus 2015. 


\section{Prosedur Penelitian}

Adapun langkah-langkah yang dilakukan oleh peneliti adalah sebagai berikut:

1. Mengumpulkan informasi untuk mengetahui gambaran umum tentang persediaan yang ada di PT. Gatraco Indah.

2. Mengetahui struktur organisasi PT. Gatraco Indah, serta tugas dan tanggung jawab masingmasing.

3. Mengetahui bagian-bagian yang bertanggungjawab dalam setiap hal yang berhubungan dengan pelaporan keuangan terutama berkaitan dengan persediaan barang yang berada di PT. Gatraco Indah.

4. Menelusuri proses pencatatan dan penilaian persediaan barang yang ada di PT. Gatraco Indah.

5. Membandingkan hasil yang diperoleh dari perusahaan dengan PSAK No.14 untuk dijadikan dasar acuan dalam menganalisa permasalahan yang ada.

6. Menarik kesimpulan.

\section{Metode Pengumpulan Data \\ Jenis Data}

Data adalah sesuatu yang belum mempunyai arti bagi penerimanya dan masih memerlukan adanya suatu pengolahan.Data bisa berwujud suatu keadaan, gambar, suara, huruf, angka, matematika, bahasa ataupun simbol-simbol lainnya yang bisa kita gunakan sebagai bahan untuk melihat lingkungan, obyek, kejadian ataupun suatu konsep. Kuncoro (2011:27) data dapat dibedakan menjadi dua jenis yaitu:

a. Data Kualitatif

Data kualitatif merupakan data yang tidak berbentuk angka (numerik) yang dapat diperoleh dari rekaman, pengamatan, wawancara atau bahan tertulis.

b. Data Kuantitatif

Data kuantitatif adalah data yang disajikan dalam bentuk angka-angka.Data yang digunakan dalam penelitian ini adalah data Kualitatif.Data kualitatif yang dibutuhkan dalam penelitian ini adalah laporan keuangan, dalam hal ini yang berhubungan dengan pencatatan persediaan yang dihasilkan oleh PT.Gatraco Indah.

\section{Sumber Data}

Sumber data terdiri atas dua jenis yaitu sebagai berikut:

a. Data primer merupakan data yang didapat/dikumpulkan langsung dari sumbernya.

b. Data sekunder merupakan data sekunder merupakan data yang didapat/dikumpulkan peneliti dari semua sumber yang telah ada dalam artian peneliti sebagai tangan kedua.

Sumber data yang digunakan dalam penelitian ini adalah data primer dan data sekunder.Data primer yang diperlukan peneliti diperoleh dengan cara wawancara.Sedangkan data sekunder yang dibutuhkan merupakan data laporan keuangan PT.Gatraco Indah Manado.

\section{Metode Analisis Data}

Data yang telah diolah kemudian dianalisis dengan menggunakan analisis deskriptif kualitatif.Analisis deskriptif kualitatif adalah analisis yang diwujudkan dengan cara menggambarkan kenyataan atau keadaan-keadaan atas suatu obyek dalam bentuk uraian kalimat berdasarkan keterangan-keterangan dari pihak-pihak yang berhubungan langsung dengan penelitian ini.

\section{Teknik Pengumpulan Data}

prosedur pengumpulan data yang dilakukan terdiri atas dua tahap, yaitu:

1. Penelitian Kepustakaan

Yaitu penelitian yang menggunakan data yang diperoleh dari tulisan tulisan ilmiah yang ada, buku-buku literature lain yang diperlukan sebagai landasan teoritis dalam penelitian ini terutama yang berhubungan dengan akuntansi persediaan baik pada perusahaan dagamh maupun manufaktur dan PSAK No.14 tentang persediaan dengan revisi terbaru (2014).

2. Penelitian Lapangan 
Yaitu penelitian langsung yang dilakukan pada perusahaan yang bersangkutan dimana ada yang diambil sebagian besar diperoleh dengan teknik pengumpulan data seperti wawancara dan observasi.

\section{Hasil Penelitian}

\section{HASIL PENELITIAN DAN PEMBAHASAN}

\section{a. Metode Pencatatan Persediaan Barang}

\section{1) Pembelian Persediaan Barang}

PT Gatraco Indah membeli sebagian besar produknya di pasar tradisional, pasar swalayan, dan juga berkerjasama dengan beberapa distributor sehingga perusahaan mendapatkan harga yang murah dengan kualitas yang dapat dijamin.Persediaan perusahaan dibagi menjadi dua yaitu persediaan bahan baku dan persediaan barang jadi (tanpa menggunakan pengolahan) Untuk mencatat persediaan bahan baku secara tunai perusahaan melakukan pencatatan sebagai berikut:

Persediaan Bahan Baku Kas $\operatorname{Rp} x x x$ $\operatorname{Rp} x x x$

Sedangkan untuk mencatat persediaan barang jadi (seperti contoh air mineral, jus, dan lainnya), perusahaan mencatatnya sebagai berikut:
Persediaan Barang Jadi
Kas
$\operatorname{Rp} x x x$
$\operatorname{Rp} x x x$

\section{2) Penggunaan Persdiaan Bahan Baku}

PT Gatraco Indah sangat menjaga keluar masuknya persediaan yang terdapat didalam gudang penyimpanan dan gudang persediaan. Untuk penggunaan bahan baku yang jangka waktu penyimpanannya tidak lama, PT Gatraco melakukan pencatatan dan mencek bahan baku dengan rutin. Untuk penggunaan persediaan bahan baku, perusahaan melakukan pencatatan sebagai berikut:
Barang dalam proses
$\operatorname{Rp} x x x$
Persediaan Bahan Baku
$\operatorname{Rp} x x x$

\section{3) Pemindahan Barang Dalam Proses ke Gudang Penyimpanan}

PT Gatraco Indah melakukan pencatatan terhadap barang yang masuk kedalam gudang penyimpanan.Gudang penyimpanan merupakan tempat dimana persediaan barang jadi disimpan.Saat pemindahan barang dalam proses ke gudang penyimpanan (Sudah menjadi barang jadi dan siap di sajikan), penjurnalan yang dilakukan adalah sebagai berikut:
Persediaan Barang Jadi
Barang dalam Proses
$\operatorname{Rp} x x x$
$\operatorname{Rp} \operatorname{xxx}$

\section{4) Persediaan Barang Jadi Dikirim}

Saat barang jadi atau siap saji telah keluar dari gudang penyimpanan, maka pihak perusahaan melakukan pencatatan sebagai berikut:
Piutang Dagang
$\operatorname{Rp} x x x$
Penjualan
$\operatorname{Rp} x x x$

\section{5) Beban Tenaga Kerja}

Beban pegawai pabrik atau beban tenagakerja juga turut menjadi terhitung dalam perhitungan biaya produksi dalam PT Gatraco Indah.Penjurnalan yang dilakukan adalah sebagai berikut:

$$
\begin{aligned}
& \text { Gaji Pegawai } \\
& \text { Utang Gaji }
\end{aligned}
$$

$\operatorname{Rp} x x x$

$$
\text { Rp xxx }
$$

\section{6) Biaya Listrik dan Air}

Selain beban gaji, biaya yang termasuk dalam biaya produksi dalam perusahaan manufaktur ini adalah biaya listrik dan juga air.Pembayaran selalu dilakukan secara tunai.Biaya-biaya ini dicatat dalam jurnal sebagai berikut: 


\begin{tabular}{|c|c|}
\hline Biaya Listrik & $\operatorname{Rp} x x x$ \\
\hline Kas & $\operatorname{Rp} x x x$ \\
\hline Biaya Air & $\operatorname{Rp} x \times x$ \\
\hline Kas & $\operatorname{Rp} x x x$ \\
\hline
\end{tabular}

\section{7) Biaya Angkut/Biaya Transportasi}

Pencatatan Biaya angkut atau biaya transportasi yang digunakan oleh PT Gatraco Indah didalam laporan keuangannya diakui sebagai piutang dagang perusahaan, dengan menggunakan FoB Shipping Point.Penjurnalan yang dilakukan adalah sebagai berikut:

$$
\begin{aligned}
\text { Biaya Transportasi } & \text { Rp xxx } \\
\text { Piutang Dagang } & \text { Rp xxx }
\end{aligned}
$$

\section{8) Pembayaran}

Produk yang dijual oleh PT Gatraco Indah semua dibayar pada awal bulan sesuai dengan tagihan yang diberikan oleh PT Gatraco Indah.Untuk pembayaran, PT. Gatraco Indah mempunyai term of payments yaitu 7 hari dimulai saat invoice dicetak.Untuk pembayaran, dijurnalkan sebagai berikut:
Kas
Piutang Dagang
$\operatorname{Rp} x x x$
$\operatorname{Rp} x x x$

\section{b. Metode Penilaian Persediaan Barang}

Dalam melakukan penilaian terhadap persediaan barang PT. Gatraco Indah Manado menggunakan metode FIFO (First In, First Out) yang berarti barang yang pertama masuk kedalam gudang penyimpanan atau gudang persediaan, barang tersebut yang pertama keluar dari gudang.

Sebagaimana yang ditulis dan dijelaskan pada PSAK No.14 (Revisi 2014) Paragraf 26 bahwa metode FIFO mengasumsikan bahwa barang persediaan yang pertama dibeli akan dijual atau akan digunakan terlebih dahulu.Dikarenakan asumsi ini, barang yang tertinggal didalam gudang penyimpanan dan gudang persediaan adalah barang yang dibeli atau diproduksi dikemudian hari.

\section{c. Pengakuan Sebagai Beban}

PT. Gatraco Indah melakukan pengakuan beban pada saat terjadi penjualan barang, yang dicatat dalam jurnal sebagai berikut:

$$
\begin{array}{rr}
\text { Harga Pokok Penjualan (HPP) } & \text { Rp xxx } \\
\text { Persediaan barang jadi } & \text { Rp xxx }
\end{array}
$$

\section{d. Pengungkapan}

Pengungkapan persediaan barang dagang yang diterapkan pada PT. Gatraco Indah Manado

Tabel 1. Kerangka Laporan Laba-Rugi PT. Gatraco Indah

\begin{tabular}{|lll|}
\hline \multicolumn{3}{|c|}{$\begin{array}{c}\text { PT. Gatraco Indah } \\
\text { Neraca }\end{array}$} \\
\hline PKTIVA & Per 31 Desember 2014 & \\
Aktiva Lancar & & \\
Kas Operasional & $\mathrm{Rp}$ & 248.000 .000 \\
Kas Dalam Bank & $\mathrm{Rp}$ & 1.095 .648 .000 \\
Piutang Dagang & $\mathrm{Rp}$ & 340.000 .000 \\
Persediaan Bahan Baku & $\mathrm{Rp}$ & 57.709 .000 \\
Persediaan Barang Jadi & $\mathrm{Rp}$ & 16.629 .000 \\
\cline { 2 - 4 } Total Aktiva Lancar & $\mathrm{Rp}$ & 1.757 .986 .000 \\
\hline
\end{tabular}

Sumber : PT. Gatraco Indah 
Tabel 2. Kerangka Laporan Laba-Rugi PT. Gatraco Indah

\begin{tabular}{|c|c|c|c|}
\hline \multicolumn{4}{|c|}{$\begin{array}{c}\text { PT. GATRACO INDAH } \\
\text { Laporan Laba-Rugi } \\
\text { Per } 31 \text { Desember } 2014\end{array}$} \\
\hline Penjualan Bersih & & \multirow{5}{*}{ Laba Bruto } & $\operatorname{Rp} \mathrm{xxx}$ \\
\hline Persediaan Akhir Tahun & & & $\operatorname{Rp} \mathrm{xxx}$ \\
\hline Harga Pokok Penjualan & & & $(\operatorname{Rp} x x x)$ \\
\hline & & & $\operatorname{Rp} \mathrm{xxx}$ \\
\hline BIAYA ADMINISTRASI \& UMUM & & & Rp $x x x$ \\
\hline BIAYA PRODUKSI & & & \\
\hline 1. Pembelian Persediaan & $\mathrm{Rp} x \mathrm{xx}$ & & \\
\hline 2. Biaya Angkut & $\operatorname{Rp} x x x$ & & \\
\hline 3. Gaji Pegawai & $\operatorname{Rp} \mathrm{xxx}$ & & \\
\hline 4. Biaya Listrik & $\operatorname{Rp} x x x$ & & \\
\hline 5. Biaya Air & $\operatorname{Rp} x x x$ & & \\
\hline TOTAL & & & Rp Xxx \\
\hline RUGI/LABA & & & $\operatorname{Rp} x x x$ \\
\hline PAJAK & & & Rp Xxx \\
\hline LABA BERSIH SETELAH PAJAK & & & $\mathrm{Rp} \mathrm{xxx}$ \\
\hline
\end{tabular}

Sumber : PT. Gatraco Indah

\section{Pembahasan}

PT. Gatraco Indah merupakan supplier makanan untuk maskapai Garuda Indonesia. Barang yang disajikan sebagian besar merupakan hasil olahan bahan baku yang PT. Gatraco Indah beli dari distributor, walaupun demikian tetap ada barang siap saji dari distributor. Tidak seperti penelitian yang dilakukan Anwar (2014) dan Sambuaga (2013) yang meneliti perusahaan dagang.

Metode pencatatan yang digunakan PT. Gatraco Indah adalah metode Perpetual, sedangkan untuk metode penilaian persediaan perusahaan menggunakan metode FIFO (First in, First Out).Untuk teknik pengukuran biaya PT. Gatraco Indah telah menerapkan metode eceran sebagai teknik pengukuran persediaan yang digunakan perusahaan, yang merupakan metode yang seringkali digunakan dalam industri eceran untuk menilai persediaan dalam jumlah besar item yang berubah dengan cepat, dam memiliki marjin yang sama di mana tidak praktis untuk menggunakan metode penetapan biaya lainnya.

\section{Kesimpulan}

\section{PENUTUP}

Hasil penelitian yang dilakukan diperoleh kesimpulan sebagai berikut:

1. Sistem pencatatan yang diterapkan pada PT. Gatraco Indah Manado dalam mencatat persediaan barang adalah sistem pencatatan perpetual. Sedangkan metode yang digunakan untuk penilaian persediaan adalah metode FIFO (First In, First Out) atau MPKP (Masuk Pertama, Keluar Pertama).

2. Pengukuran persediaan pada PT. Gatraco Indah Manado yang merupakan perusahaan manufaktur khusus untuk maskapai penerbangan Garuda Indonesia membebankan seluruh biaya yang terlibat dalam menghasilkan barang jadi dan siap diangkut.

3. Pengungkapan persediaan yang disajikan dalam laporan keuangan pada PT. Gatraco Indah Manado telah sesuai dengan Standar Akuntansi Keuangan yang berlaku di Indonesia. 
4. Secara keseluruhan PT. Gatraco Indah Manado telah sesuai dengan PSAK No. 14 (Revisi 2014), baik dalam metode pencatatan, penilaian, persediaan, pengukuran maupun pengungkapan persediaan.

\section{Saran}

Saran yang diberikan penulis adalah sebagai berikut:

1. Prosedur pencatatan dan penilaian persediaan barang yang diterapkan oleh PT. Gatraco Indah Manado telah dijalankan dengan baik dan sesuai dengan Standar Akuntansi yang berlaku, sehingga harus dipertahankan.

2. Dalam rangka pengembangan sistem informasi, disarankan agar perusahaan memiliki aplikasi yang di design khusus untuk pencatatan akuntansi perusahaan, agar memudahkan perusahaan serta meminimalisir adanya kesalahan pencatatan.

\section{DAFTAR PUSTAKA}

Anwar, Nurul F. 2014.Analisis Penerapan Metode Pencatatan dan Penilaian Terhadap Persediaan Barang Menurut PSAK No.14 pada PT. Tirta Investama Manado . Jurnal EMBA. ISSN 23031174 No.2. Vol.2. Jurusan Akuntansi, Fakultas Ekonomi dan Bisnis Universitas Sam Ratulangi. http://ejournal.unsrat.ac.id/index.php/emba/article/view/4715/4238.Tanggal akses 14 Maret 2015.Hal. 1296-1305

Ardiyos. 2010. Kamus Besar Akuntansi.Cetakan kelima, Citra Harta Prima. Jakarta.

Belkaoui, 2011.Accounting Theory.Edisi Kelima. Salemba Empat, Jakarta.

Djanegara, H. 2004. Evaluasi Metode Penilaian Persediaan Kaitannya Dengan Harga Pokok Penjualan. Jurnal Ilmiah Ranggagading Vol.4 No.1.Sekolah Tinggi Ilmu Ekonomi Kesatuan.

Ikatan Akuntan Indonesia. 2015. Standar Akuntansi Keuangan. Cetakan kedua. Dewan Standar Akuntansi Keuangan Ikatan Akuntan Indonesia, Jakarta.

Keown, Arthur J., Martin, John D., Petty J William dan Scoot Jr, David F., 2010. Manajemen Keuangan: Prinsip dan Penerapan.Jilid 2. Edisi Kesepuluh. PT. Indeks, Jakarta.

Kuncoro, Mudjarad. 2011. Metode Kuantitatif Teori dan Aplikasi Untuk Bisnis dan Ekonomi. YPKN, Yogyakarta.

Pontoh, Winston.2013. Akuntansi : Konsep dan Aplikasi, Halaman Moeka. Jakarta

Reeve, James R., Warren, dkk.2009. Pengantar Akuntansi - Adaptasi IndonesiaBuku 1. Salemba Empat, Jakarta Selatan.

Sambuaga, Reinhard S. 2013. Evaluasi Akuntansi Persediaan pada PT. Sukses Era Niaga Manado.Jurnal EMBA. ISSN 2303-1174 No.4. Vol.1. Jurusan Akuntansi, Fakultas Ekonomi dan Bisnis Universitas $\quad$ Sam http://ejournal.unsrat.ac.id/index.php/emba/article/view/3349/2899.Tanggal akses 14 Maret 2015.Hal. 1697-1705

Supriyono. 2008. Akuntansi Biaya. Penentuan Harga Pokok dan Pengendalian Biaya Edisi Kelima. Cetakan Sebelas, Yogyakarta. 